\title{
Mass budgets of the Lambert, Mellor and Fisher Glaciers and basal fluxes beneath their flowbands on Amery Ice Shelf
}

\author{
WEN JiaHong ${ }^{1,2 \dagger}$, Kenneth C. JEZEK ${ }^{2}$, Beata M. CSATHÓ ${ }^{2}$, Ute C. HERZFELD ${ }^{3}$, \\ Katy L. FARNESS ${ }^{2}$ \& Philippe HUYBRECHTS ${ }^{4,5}$ \\ ${ }^{1}$ Department of Geography, Shanghai Normal University, Shanghai 200234, China; \\ ${ }^{2}$ Byrd Polar Research Center, The Ohio State University, Columbus, OH 43210, USA; \\ ${ }^{3}$ CIRES/NSIDC, University of Colorado Boulder, Boulder, CO 80309-0449, USA; \\ ${ }^{4}$ Departement Geografie, Vrije Universiteit Brussel, Pleinlaan 2, B-1050, Brussels, Belgium; \\ ${ }^{5}$ Alfred-Wegener-Institut für Polar- und Meeresforschung, Postfach 120161, D-27515 Bremerhaven, Germany
}

We used in situ measurements and remote-sensing data sets to evaluate the mass budgets of the Lambert, Mellor and Fisher Glaciers and the basal melting and freezing rates beneath their flowbands on the Amery Ice Shelf. Our findings show the Lambert and Mellor Glaciers upstream of the ANARE Lambert Glacier Basin (LGB) traverse may have positive imbalances of $3.9 \pm 2.1 \mathrm{Gt} \mathrm{a}^{-1}$ and $2.1 \pm 2.4 \mathrm{Gt} \mathrm{a}^{-1}$, respectively, while the Fisher Glacier is approximately in balance. The upstream region as a whole has a positive imbalance of $5.9 \pm 4.9 \mathrm{Gt}^{-1}$. The three same glaciers downstream of the ANARE LGB traverse line are in negative imbalance, where the whole downstream region has a negative imbalance of $-8.5 \pm 5.8 \mathrm{Gt} \mathrm{a}^{-1}$. Overall the mass budgets of the Lambert, Mellor, and Fisher Glaciers are close to balance, and the collective three-glacier system is also nearly in balance with a mass budget of $-2.6 \pm 6.5 \mathrm{Gt}$ $\mathrm{a}^{-1}$. The significant positive imbalances for the interior basin upstream of the ice-movement stations established in the early 1970s (GL line) reported previously are possibly due to an overestimate of the total accumulation and an underestimate of the ice flux through the GL line.

The mean melting rate is $-23.0 \pm 3.5 \mathrm{~m}$ ice $\mathrm{a}^{-1}$ near the southern grounding line, which decreases rapidly downstream, and transitions to refreezing at around $300 \mathrm{~km}$ from the southern extremity of the Amery Ice Shelf. Freezing rates along the flowbands are around $0.5 \pm 0.1$ to $1.5 \pm 0.2 \mathrm{~m}$ ice $\mathrm{a}^{-1}$. The percentage of ice lost from the interior by basal melting beneath the flowbands is about $80 \% \pm 5 \%$. The total basal melting and refreezing beneath the three flowbands is $50.3 \pm 7.5 \mathrm{Gt}$ ice $\mathrm{a}^{-1}$ and $7.0 \pm 1.1 \mathrm{Gt}$ ice $\mathrm{a}^{-1}$, respectively. We find a much larger total basal melting and net melting than the results for the whole Amery Ice Shelf derived from previous modeling and oceanographic measurements.

mass budget, basal melting and freezing, Lambert Glacier Basin, Amery Ice Shelf, East Antarctica

\section{Introduction}

The Antarctic Ice Sheet holds approximately $90 \%$ of the ice in the world so that even a small imbalance between snowfall and discharge of ice and meltwater into the ocean could significantly alter global sea level. Many authors have made estimates of the mass balance of the entire ice sheet $\frac{[1-6]}{}$ as well as individual drainage sys- tems ${ }^{[7,8]}$. The fourth assessment report of the Intergovernmental Panel on Climate Change suggests that mass

Received November 24, 2006; accepted June 28, 2007 doi: 10.1007/s11430-007-0120-y

'Corresponding author (email: jhwen@shnu.edu.cn)

Sponsored by the NASA's Polar Oceans and Ice Sheets Program, the National Natural Science Foundation of China (Grant Nos. 40471028, 40231013 and 40476005), and the Shu Guang Project supported by Shanghai Municipal Education Commission and Shanghai Education Development Foundation (Grant No. 05SG46) 
losses from Antarctic Ice Sheet have likely contributed to sea level rise over the past 30 years, the assessment uncertainty, however, is still very large ${ }^{1)}$, studies on Antarctic Ice Sheet mass balance are increasingly of importance and necessity in context of the global warming ${ }^{[9]}$.

Complicating mass balance estimates is the fact that much of the coastline of Antarctica is fringed by floating ice shelves. The basal flux beneath the $1.6 \times 10^{6} \mathrm{~km}^{2}$ ice shelf area ${ }^{[10]}$ is not only an important component of the Antarctic mass budget, but also a key factor in the modification of the characteristics of the ocean and a significant contributor to the Antarctic Bottom Water formation. Studies ${ }^{[3,11]}$ indicate that rapid bottom melting is widespread near the Antarctic Ice Sheet grounding lines, and that the net basal melting may account for up to one thirds of the loss from the floating ice. The basal flux beneath the ice shelves is probably still the least well known element of the Antarctic mass budget, though remarkable advances have been achieved since Jenkins and Doake ${ }^{[12]}$ studied ice-ocean interaction on the Ronne Ice Shelf by means of detailed glaciological measurements.

Recent advances in remote sensing (particularly laser altimetry, radar altimetry, interferometric synthetic-aperture radar (InSAR), Global Positioning System (GPS), and gravity-field measurement) have resulted in a substantial increase in our ability to estimate the mass balance of polar ice sheets. InSAR has been used to measure glacier velocities and map grounding-line positions $\frac{[13-15]}{}$. Radar and laser altimetry have been used to map the topography of the ice sheet, and are unprecedented in terms of spatial extent and accuracy $\frac{[16-18]}{\text {. }}$ These technical advances allow us to obtain a more precise estimate of the mass budgets of Lambert Basin and basal fluxes beneath the Amery Ice Shelf. The Lambert Basin and the Amery Ice Shelf constitute one of the largest glacier systems in Antarctica. We use standard glaciological methods ${ }^{[3,19]}$ combined with other data sets, such as snow accumulation ${ }^{[20,21]}$ and ice thickness ${ }^{[22]}$ compilations. We present estimates of the mass budgets of the Lambert, Mellor and Fisher Glaciers, upstream and downstream of the ANARE (Australian Antarctic Expedition) LGB traverse, and melting and freezing rates beneath the flowbands on the Amery Ice Shelf originating from those glaciers using a GIS (geographic information system) environment to combine a variety of data sets derived from in situ measurements and remote sensing data sets.

\section{Study area}

Our study area covers the central part of the Lambert Glacier-Amery Ice Shelf system (hereafter, LAS), East Antarctica (Figure 1). We use the Fricker et al. ${ }^{[23,24]}$ definition of the LAS, but the front of the Amery Ice Shelf is defined by the RAMP (RADARSAT-1 Antarctic Mapping Project) image mosaic ${ }^{[25]}$. Located at $68.5-$ $81^{\circ} \mathrm{S}, 40-95^{\circ} \mathrm{E}$, it is the second largest glacier-ice-shelf system in East Antarctica, and an important drainage basin in terms of the overall mass balance of Antarctica ${ }^{[24]}$. The grounded portion of our study area corresponds to the Lambert Glacier drainage basin defined by Rignot $^{[15]}$, which contains the three glaciers draining into the rear of the Amery Ice Shelf.

As defined by Allison ${ }^{[26]}$, the Lambert Glacier, fed by its three tributaries (the Lambert, Mellor and Fisher Glaciers), was considered the largest grounded ice stream in the world. Fricker et al. ${ }^{[27]}$ and Rignot ${ }^{[15]}$ revised the total length of the glacier by showing that the grounding-line position of the Lambert Glacier was located much further south (up to $240 \mathrm{~km}$ ) than the previously reported position ${ }^{[28]}$, based on hydrostatic equilibrium and InSAR data. The newly determined grounding line is located in the zone of confluence of the Lambert, Mellor and Fisher Glaciers.

We used the OSU digital elevation model (DEM) ${ }^{[16]}$ in Arc/Info grid format to define the upstream boundary of the LAS by applying hydrology tools available in the proprietary GIS, ArcGIS Desktop (Version 8.3). Two functions FlowDirection and Basin in the hydrology tools can find the direction of steepest descent from each cell and identify ridge lines between basins. The grounding line of the Lambert, Mellor and Fisher Glaciers (the southern grounding line, Figure 2), mapped interferometrically by Rignot ${ }^{[15]}$, is used in this study. The resulting precision of grounding-line mapping is $100 \mathrm{~m}$ for the Lambert Glacier and $300 \mathrm{~m}$ for Mellor and Fisher Glaciers ${ }^{[15]}$. The boundaries of the three tributary glaciers are delineated by tracing the flow stripes ${ }^{[29]}$ or

1) IPCC. Climate Change 2007: The Physical Science Basis Summary for Policymakers. Paris, February 2007 


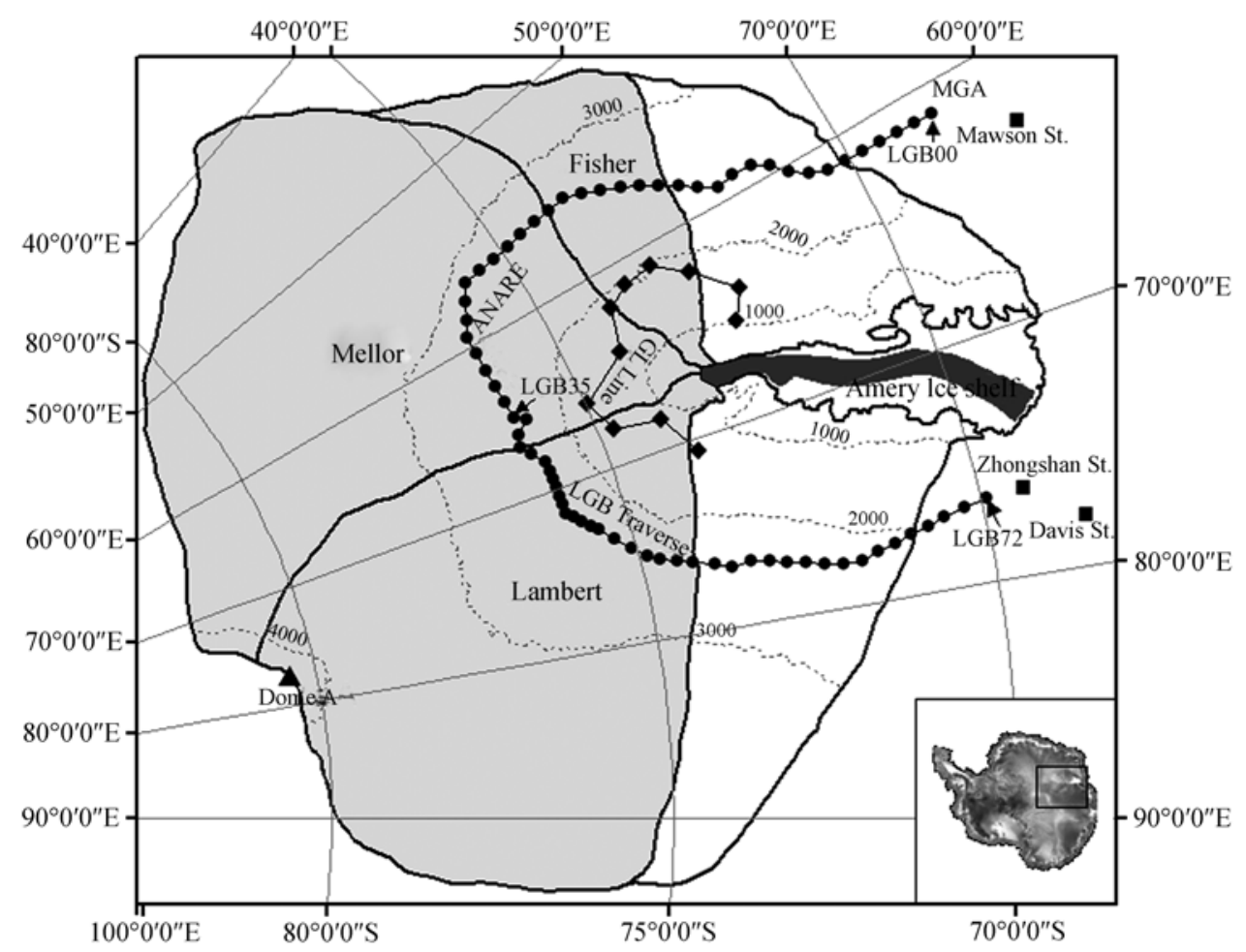

Figure 1 Map of the LAS, showing the location of the Lambert, Mellor and Fisher glaciers (in light grey) and their flowbands (in dark grey), GPS stations (dot) along the ANARE LGB traverse route and the ice movement stations (diamond) along the GL line. Elevation contours are shown as dashed lines with a $1000 \mathrm{~m}$ interval.

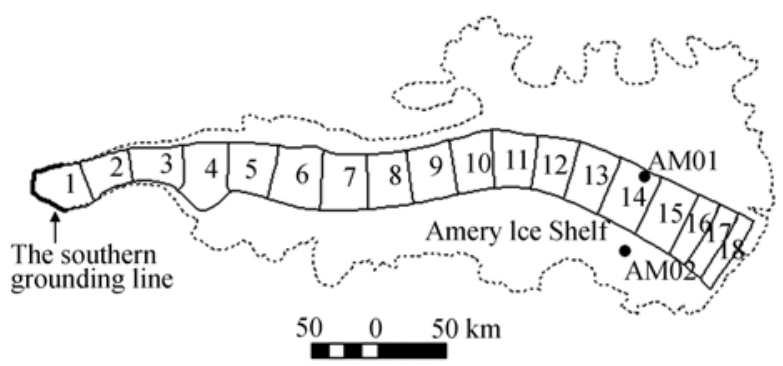

Figure 2 A sketch showing the ice flux gates and their number placed over the flowbands on the Amery Ice Shelf, the southern grounding line (thick line), i.e., the grounding line of Lambert, Mellor, Fisher glaciers at the rear of the ice shelf, the locations of two access holes (AM01 and AM02), and the margin of the ice shelf (dash line).

foliation trends ${ }^{[30]}$ observed in the RAMP mosaicfor the lower elevation portion (lower than around 2000-2500 $\mathrm{m})$, and then tracing the steepest paths generated from the OSU-DEM $5 \mathrm{~km}$ triangular irregular network surface. The upstream and downstream drainages of these glaciers are defined by the ANARE LGB traverse line (Figure 1).

Velocity data in vector form with a spacing interval of 2 by $2 \mathrm{~km}$ derived from the Modified Antarctic Mapping Mission (MAMM) InSAR project ${ }^{[31]}$ are plotted over the Amery Ice Shelf. The boundaries of the Lambert, Mellor and Fisher flowbands were drawn by tracing the flow directions. Eighteen ice flux gates normal to the velocity vector were placed at intervals of 30 to $40 \mathrm{~km}$ for gates 1 to 15 , and around $15 \mathrm{~km}$ for gates 16 to 18 over the flowbands (Figure 2).

The study area (original projection is polar stereographic) was re-projected to the Lambert azimuthalequal area to calculate the area values. The total grounded area of Lambert, Mellor and Fisher Glaciers is $970610 \mathrm{~km}^{2}$.

\section{Previous mass budget and basal flux studies}

Fricker et al. ${ }^{[24]}$ briefly summarized previous mass balance studies of the interior LAS basin (the Lambert Glacier drainage basin, LGDB), which is a part of the system that drains through the major ice streams entering the rear of the Amery Ice Shelf. Earlier studies typically estimated a large positive mass imbalance for the interior drainage basin. For example, Allison ${ }^{[26]}$ estimated mass fluxes for the LGDB, of approximately $30 \mathrm{Gt} \mathrm{a}^{-1}$ (50\% of total net accumulation), obtaining an overall positive imbalance for the interior (upstream of the GL 
line, Figure1), and a positive mass balance of $12 \mathrm{Gt} \mathrm{a}^{-1}$ between the grounding line and the GL line. Bentley and Giovinetto ${ }^{[1]}$ obtained a positive mass imbalance of 39 $\mathrm{Gt} \mathrm{a}^{-1}$ (78\% of total net accumulation) for the entire LGDB though McIntyre ${ }^{[32]}$ re-assessed the mass balance of the LGDB and suggested a positive mass balance for the interior basin $\left(+2 \mathrm{Gt} \mathrm{a}^{-1}\right)$ and error limits which fell below zero by re-definition of the basin and reinterpretation of surface accumulation based on satellite imagery.

Fricker et al. ${ }^{[24]}$ estimated the total integrated mass flux across the ANARE LGB traverse of $44 \mathrm{Gt} \mathrm{a}^{-1} \mathrm{de}-$ rived from observations along the LGB traverse line between LGB05 and LGB69 with an assumed surface velocity factor of 0.87 . They also assessed the mass balance of the region between the LGB and GL lines with six different accumulation distributions, with four of the estimates exceeding $+30 \%$, which strongly suggested that the mass balance of the region between the two lines was positive. A new grounding line of the Lambert Glacier drainage basin was defined using InSAR, which resulted in the mass balance estimate of the basin being close to balance ${ }^{[15]}$. This suggests that prior estimates of large positive mass imbalances for LGDB were due to incorrect positioning of the grounding line. Mass losses between the new ${ }^{[15]}$ and old ${ }^{[28]}$ grounding lines were accounted for in prior estimations of the mass budget of this glacier system. The mass imbalance anomalies upstream of the GL line ${ }^{[24,26]}$, however, still cannot be explained by the new mapping of the grounding line location.

Basal melting and freezing beneath the Amery Ice Shelf have been investigated over the last five decades by means of field measurements ${ }^{[28,33]}$, ice core drilling $^{[34]}$, modeling ${ }^{[35-37]}$, etc. Freezing of up to $0.6 \mathrm{~m} \mathrm{a}^{-1}$ has been reported for the Amery Ice Shelf, supported by a thick layer of basal marine ice at the "G1" drill site near $69^{\circ} 27^{\prime} \mathrm{S}, 71^{\circ} 42^{\prime} \mathrm{E}$ and glaciological mass balance calculations $^{[28,34]}$. Recently, this has been confirmed by the work of Fricker et al. ${ }^{[38]}$, who mapped the accreted marine ice beneath the Amery Ice Shelf. The thickness distribution of the marine ice, predicted to be up to 190 $\mathrm{m}$ thick in places, was estimated from hydrostatic anomalies. An access hole through the shelf drilled by ANARE at AM01 $\left(69^{\circ} 26.5^{\prime} \mathrm{S}, 71^{\circ} 25.0^{\prime} \mathrm{E}\right)$ in $2001 / 02$ and a 300-m ice core recovered nearby by CHINARE (Chinese Antarctic Expedition) in 2002/03 field season suggested the marine ice layer there was $200 \mathrm{~m}$ thick. Es- timates based on InSAR data yielded local melt rates of $31-32 \pm 5 \mathrm{~m}$ ice $\mathrm{a}^{-1}$ near the southern grounding line ${ }^{[11,15]}$. Using hydrographic observations collected near the front of the Amery Ice Shelf, Wong et al. ${ }^{[33]}$ estimated that the amount of ice lost from the bottom of the Amery Ice Shelf ranged between $10.7 \mathrm{Gt} \mathrm{a}^{-1}$ and $21.9 \mathrm{Gt} \mathrm{a}^{-1}$. Hellmer and Jacobs ${ }^{[35]}$ modeled the subAmery ocean thermohaline circulation as a channel flow with seasonal forcing, which indicated a mean melting rate as high as $0.65 \mathrm{~m} \mathrm{a}^{-1}$ for this ice shelf, equal to the removal of $23 \mathrm{Gt} \mathrm{a}^{-1}$ of basal ice. Williams et al. ${ }^{[37]}$ used a three-dimensional numerical ocean model to simulate the ocean cavity beneath the Amery Ice Shelf with two different boundary conditions. The two simulations gave net melt rates of $5.8 \mathrm{Gt} \mathrm{a}^{-1}$ and $18.0 \mathrm{Gt} \mathrm{a}^{-1}$, respectively. Both models showed basal freezing of several Gt $\mathrm{a}^{-1}$. Hellmer ${ }^{[36]}$ also reported a spatial average basal melting rate of $0.35 \mathrm{~m}$ ice $\mathrm{a}^{-1}$, and the total basal mass loss of $17.65 \mathrm{Gt} \mathrm{a}^{-1}$ beneath the Amery Ice Shelf, using a coupled ice-ocean model.

\section{Data sets and methodology}

The data sets used in this study include the MAMM InSAR velocity data ${ }^{[31,39]}$, the RAMP image mosaic ${ }^{[25]}$, the OSU-DEM ${ }^{[16]}$, ICESat GLAS (Geoscience Laser Altimeter System) laser altimeter data ${ }^{[40]}$, AIS-DEM (the Amery Ice Shelf DEM) ${ }^{[23]}$, ANTARCTIC ATLAS$\operatorname{DEM}^{[18]}$, BEDMAP (A new ice thickness and subglacial topographic model of the Antarctic) ice thickness ${ }^{[22]}$, surface accumulation data sets by Vaughan et al. ${ }^{[20]}$ and Giovinetto (Giovinetto and Zwally ${ }^{[21]}$, modified by Giovinetto) (hereafter, Vaughan and Giovinetto compilations respectively), velocity ratio derived from a model simulation of the ice sheet ${ }^{[41]}$, and in situ measurements collected by ANARE and CHINARE.

Three approaches have been used to determine the mass balance of Antarctic glaciers, all with their own advantages and limitations ${ }^{[3]}$. The approach considered here is commonly referred to as the mass-budget ${ }^{[15]}$, or component (flux) method ${ }^{[9]}$ in which the input and output fluxes are individually measured or estimated, and mass budget is determined by the differences between the total input for each catchment area and the corresponding ice flux through the traverse line or the grounding line. The basal melting and freezing rates are estimated assuming mass conservation and steady-state 
conditions between the gates placed over the flowbands of Lambert, Mellor and Fisher Glaciers, similar to the method used by Rignot and Jacobs ${ }^{[11]}$.

\subsection{MAMM InSAR velocity products}

The principal objective of the MAMM project that occurred during the fall of 2000 was to obtain surface velocities on the ice sheet ${ }^{[31]}$. MAMM acquired data from about $80^{\circ} \mathrm{S}$ latitude to the Antarctic coast, with three repeat cycles in descending orbit mode and three repeat cycles in ascending orbit mode. Ice velocity can be measured interferometrically combining ascending and descending passes to obtain a vector measurement of ice velocity ${ }^{[42]}$. This technique has an inherent precision of a couple of meters per year, in practice better than 10 $\mathrm{m} \mathrm{a}^{-1[15]}$. The velocity data in vector form from the MAMM were produced with a spacing interval of 400 m.

Areas with no velocity data are due to some gaps in the RADARSAT SAR image or weak coherence between a pair of images used for InSAR velocity mapping. Kriging was applied to interpolating these patches (Figure 3).

\subsection{DEMs}

DEMs are used to convert surface topography to ice thickness on the floating ice shelf, assuming hydrostatic equilibrium. Unfortunately, there are almost no ice radar thickness data available along the southern grounding line. Over the northern portion of the flowbands the marine ice accretes onto the base of the shelf. Airborne radio-echo sounding (RES) measurement detects only the meteoric-marine ice as the RES signal does not penetrate the marine ice ${ }^{[38]}$.

For the purpose of improving the basal flux estimate, three DEMs generated from the European Remote
Sensing Satellite (ERS-1) radar altimeter using different data processing and interpolation schemes are used in our analysis. The AIS-DEM and ANTARCTIC-ATLAS DEM, with different horizontal resolutions, are interpolated onto the same $400 \mathrm{~m}$ cell-size grid as are the InSAR velocity map and the OSU-DEM. The OSU-DEM, with a $400 \mathrm{~m}$ cell-size grid, has a vertical accuracy better than $2 \mathrm{~m}$ for the central portion of the Amery Ice Shelf $\frac{[16]}{}$. The AIS-DEM (1 km grid), with a RMS error of $1.7 \mathrm{~m}$ in vertical accuracy ${ }^{[23]}$, is bilinearly resampled to a $400 \mathrm{~m}$ cell-size grid. On the flat Amery Ice Shelf the error of the ANTARCTIC ATLAS-DEM (3 km grid) is typically less than $3 \mathrm{~m}^{[18]}$. This DEM was interpolated to the $400 \mathrm{~m}$ cell-size grid using kriging.

A fourth DEM, created in this study based on the ICESat GLAS data, is used for ice flux calculation across the southern grounding line and gates 1 and 2 (Figure 2).

An attempt to infer ice thickness from the OSU-DEM, AIS-DEM and ANTARCTIC ATLAS-DEM was unsuccessful due to relatively large errors in some sections along the grounding line, so the ICESat GLAS data (version 18 data from L1 and L2a) are used to generate an improved DEM for the southern grounding line region $^{[40]}$. The ICESat GLAS data have a sensor footprint of $75 \mathrm{~m}$, and a typical along-track spacing between footprints is $175 \mathrm{~m}$ on the ground with an across-track separation of several kilometers ${ }^{[40]}$. Such spacing shares the same distribution properties with many other geographical or geological data surveys that are carried out from vehicles that follow tracks; i.e., the data are densely sampled along tracks while the flight tracks themselves are widely spaced. Such a distribution poses serious difficulties for most interpolation techniques and results in a directional bias in the grid $^{[22]}$. To counter

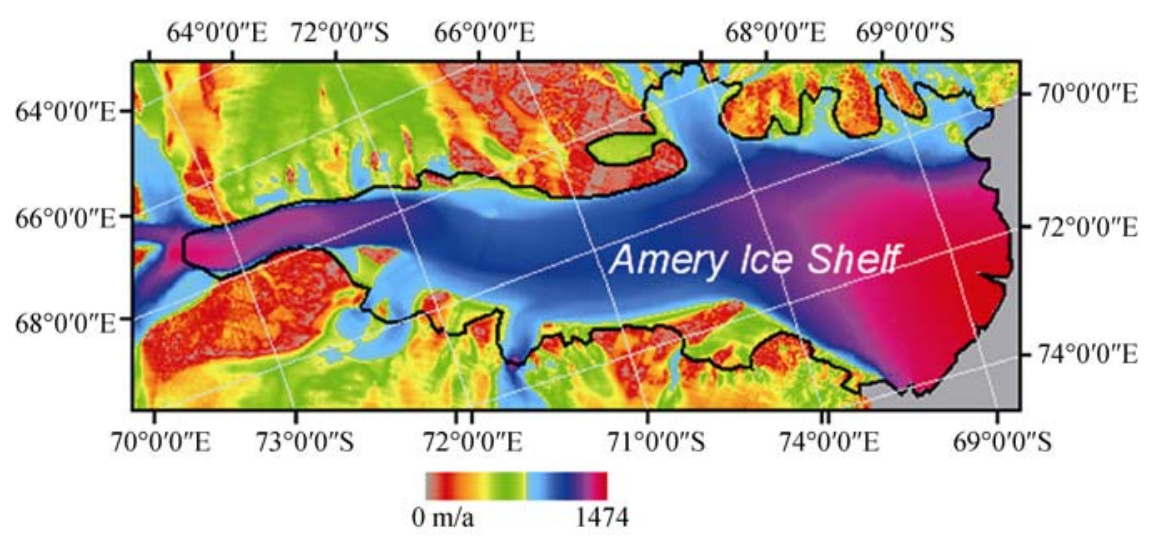

Figure 3 Ice velocity for the Amery Ice Shelf and its neighborhood determined by the MAMM InSAR velocity mapping. 
this, we reprocessed the data so that the spacing was larger than $2000 \mathrm{~m}$. A cokriging technique was then applied to create a continuous surface (GLAS-DEM) with the OSU-DEM as another variable assuming it has a correct elevation trend though the errors are relatively large around the southern grounding line of the Amery Ice Shelf.

The AIS-DEM, ANTARCTIC-ATLAS DEM, and GLAS-DEM were converted to orthometric heights relative to the OSU91A geoid ${ }^{[43]}$ while the OSU-DEM used this geoid originally ${ }^{[15]}$.

\subsection{Ice thickness}

(i) BEDMAP ice thickness. A total of 159871 points of ice thickness data over the Amery Ice Shelf and neighboring regions, measured by the Australian and Russian Antarctic expeditions using airborne radio echo sounding (RES), ground-based RES, and seismic reflection \& gravity since the 1950 s, were downloaded from the BEDMAP website (http://www.antarctica.ac.uk/ aedc/bedmap $/)^{[22]}$. After cross-validation, 1375 ice thickness data points from Mission-ID 8 collected by ANARE in 1968 and ground-based RES data collected in 1970/71 were excluded due to large biases $(>200 \mathrm{~m})$ with neighboring data. The ice thickness data were then interpolated onto a $400 \mathrm{~m}$ cell-size grid using kriging.

(ii) Column-averaged ice density and ice thickness derived assuming hydrostatic equilibrium. Fricker et al. ${ }^{[39]}$ presented the column-averaged ice density over the Amery Ice Shelf, which was derived from a density model that has two layers of meteoric ice to account for a firn layer plus a marine ice layer at the base of the shelf. Here we also used a density of $921 \mathrm{~kg} \mathrm{~m}^{-3}$ near the grounding line, which was essentially inferred from ice temperature ${ }^{[27,39]}$.

In 2000/01 and 2001/02, access holes were drilled through the shelf by a hot-water drilling system at two sites: AM02 $\left(69^{\circ} 42.8^{\prime} \mathrm{S}, 72^{\circ} 38.4^{\prime} \mathrm{E}\right)$, located $\sim 80 \mathrm{~km}$ south of the calving front, and AM01 $\left(69^{\circ} 26.5^{\prime} \mathrm{S}\right.$, $71^{\circ} 25.0^{\prime} \mathrm{E}$ ), located $\sim 50 \mathrm{~km}$ west of AM02, and $\sim 100 \mathrm{~km}$ from the floating ice shelf edge (Figure 2). The ice shelf at AM01 is $373 \mathrm{~m}$ thick while at AM02 it is $479 \mathrm{~m}$ thick, the lower $200 \mathrm{~m}$ of which is marine ice ${ }^{[44]}$. The column-averaged densities, $904.7 \mathrm{~kg} \mathrm{~m}^{-3}$ and $899.5 \mathrm{~kg} \mathrm{~m}^{-3}$ at AM01 and AM02 respectively, are deduced using a seawater density of $1028 \mathrm{~kg} \mathrm{~m}^{-3}[33]$ and the average elevations from the three DEMs and the GPS elevation data nearby.
An alternate estimate of column-averaged density of $885 \mathrm{~kg} \mathrm{~m}^{-3}$ is obtained from a 300 -meter ice core recovered at a site about $300 \mathrm{~m}$ away from AM01 assuming the density of the entire marine ice density is equal to the average density of the marine ice at the bottom $25 \mathrm{~m}$ of the ice core. There are two possibilities for this smaller density value. First, some part of the ice core might have been broken during the core drilling, even though it was assumed to be integrated when the dimensions were measured in situ. Second, the bottom $25-\mathrm{m}$ marine ice density $\left(913 \mathrm{~kg} \mathrm{~m}^{-3}\right)$ was used as a proxy of the average density of the entire marine ice $(200 \mathrm{~m}$ thick), which perhaps also underestimates the actual density as the density of marine ice could become more dense with depth due to increased salinity. Therefore, the density around AM01 and AM02 is likely to be 890$900 \mathrm{~kg} \mathrm{~m}^{-3}$.

First, we generated three density models on the $400 \mathrm{~m}$ grids by linearly interpolating the density of $921 \mathrm{~kg} \mathrm{~m}^{-3}$ at the southern grounding line and 890,895 , and $900 \mathrm{~kg}$ $\mathrm{m}^{-3}$ at AM01. Three ice thickness maps were obtained by converting the AIS-DEM using these three density models. Three distributions of marine ice thickness beneath the Amery Ice Shelf are then derived by subtracting the Russian ice radar data in the same manner as Fricker et al. ${ }^{[38]}$. The RES records show strong basal echoes under the eastern (south of $71.3^{\circ} \mathrm{S}$ ) and the

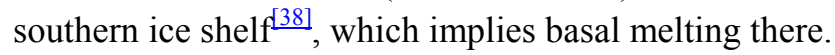
Comparing the three marine ice distribution maps, we suggest the density of $895 \mathrm{~kg} \mathrm{~m}^{-3}$ at AM01 is reasonable. At last, the column-averaged ice density distribution is modified approximately along the ice flow direction by minimizing the hydrostatic height anomaly, namely the difference between the measured surface height and the surface height calculated from measured ice thickness ${ }^{[38]}$. The new density distribution includes three portions, 921 to $914.7 \mathrm{~kg} \mathrm{~m}^{-3}$ between 0 (the southern grounding line) and $215 \mathrm{~km}, 914.7$ to $903.5 \mathrm{~kg} \mathrm{~m}^{-3}$ between 215 and $315 \mathrm{~km}$, and 903.5 to $890.5 \mathrm{~kg} \mathrm{~m}^{-3}$ from $315 \mathrm{~km}$ to the calving front, which approximately passes through AM01 with the density of $895 \mathrm{~kg} \mathrm{~m}^{-3}$. Column-averaged density decreases linearly within each portion.

Ice thickness $(Z)$ distributions can then be generated from the OSU-DEM, AIS-DEM, ANTARCTIC ATLASDEM and the GLAS-DEM surface elevation $(H)$ in an Arc/Info environment, using the above density $\left(\rho_{i}\right)$ distribution, and applied by the hydrostatic equation: $Z=$ 
$\rho_{w} H /\left(\rho_{w}-\rho_{i}\right)$, where $\rho_{w}$ is the sea-water density of 1028 $\mathrm{kg} \mathrm{m}^{-3}$.

\subsection{Measured surface ice velocity and ice thickness from the LGB traverse}

During 1989-1995, seventy-three ice-movement stations (LGB00-LGB72) were established along the ANARE LGB traverse route. The stations are typically positioned at $30 \mathrm{~km}$ intervals along the traverse route as shown in Figure 1. Across the Lambert Graben the stations have been positioned at intervals of $15 \mathrm{~km}$ in order to resolve a more detailed ice velocity in this region. At each station, surface ice-flow velocity magnitude and azimuth were precisely surveyed by GPS in at least two separate years. The mean $(2 \sigma)$ precision of the GPS velocity result is $0.108 \mathrm{~m} \mathrm{a}^{-1}$. All but two of these ice-velocity determinations had an estimated accuracy of better than $1 \mathrm{~m} \mathrm{a}^{-1}$, and about $60 \%$ had an estimated accuracy better than $0.3 \mathrm{~m} \mathrm{a}^{-1}[24,45,46]$. Ice thickness was also measured about every $10 \mathrm{~m}$ along the traverse and averaged over $2 \mathrm{~km}$ intervals by a $100 \mathrm{MHz}$ digital ice radar system. The resolution of the individual soundings is about $20 \mathrm{~m}$. In order to supplement radio echo sounding data in some short sections where either poor or no signal returns were obtained, measurements of the local gravity field were taken at $2 \mathrm{~km}$ intervals using LaCoste $\&$ Romberg Model G gravity meters ${ }^{[47]}$.

\subsection{Total accumulation}

Following Joughin and Tulzczyk ${ }^{[14]}$ and Rignot ${ }^{[15]}$, we estimated integrated accumulation using the average of the Vaughan and Giovinetto compilations that were based on essentially the same source data using different analysis and interpolation criteria ${ }^{[21]}$. These two accumulation compilations were interpolated onto $5 \mathrm{~km}$ cell-size grid using kriging, and then the mean value was determined on a cell-by-cell basis.

The total accumulation for each sub-basin is equal to its area multiplied by the annual accumulation rate averaged over the area using the ArcGIS zonal statistic tools which calculate statistics based on values of a raster within zones. The accumulation totals for the two compilations differ by $\sim 10 \%$ upstream and downstream of the ANARE LGB traverse line, which is indicative of the variability introduced by regridding ${ }^{[14]}$. Thus we use a value of $10 \%$ for the accumulation map error in individual glacier drainages. The catchment area error is assumed to be $5 \%$, and $11.2 \%$ for the error in the catch- ment-wide accumulation totals.

\subsection{Ice fluxes through the ANARE LGB traverse line and the grounding line}

The ice fluxes through the traverse line between adjacent GPS stations are estimated as the product of surface ice velocity, ice thickness, and velocity ratio, equal to column-averaged velocity divided by surface velocity ${ }^{[48,49]}$. The velocity was converted into its equivalent value normal to the traverse line ${ }^{[14]}$. Ice velocities were interpolated between adjacent GPS stations, assuming linear change in speed and direction between the two measured values ${ }^{[50]}$. The velocity ratio is derived from a model simulation of the Antarctic Ice Sheet with a 3D thermomechanical ice-sheet model that takes into account basal sliding and a variable temperature with $\operatorname{depth}^{[41]}$. The ice fluxes for the Lambert, Mellor and Fisher Glaciers through the ANARE traverse line were computed as the integral of ice fluxes between the adjacent GPS stations. The errors involved in calculating the total ice discharge include errors in measurements of ice velocity and its direction, ice thickness, and the assumed velocity ratio. We use a value of 5\% for the total error in calculated ice-discharge flux, which is consistent with the error analysis by ref. [48].

The ice flux across the grounding line was estimated as stated above assuming the velocity ratio is equal to 1 . The velocity magnitude and azimuth with $400 \mathrm{~m}$ by 400 $\mathrm{m}$ spacing, derived by the MAMM project, are used. The ice thickness ranging from $2000-3000 \mathrm{~m}$ along the grounding line was deduced from the GLAS-DEM by a hydrostatic equilibrium equation assuming the densities of column-averaged ice and ocean water are $921 \mathrm{~kg} \mathrm{~m}^{-3}$ and $1028 \mathrm{~kg} \mathrm{~m}^{-3}$ respectively ${ }^{[27,38]}$. The ice thickness derived from the GLAS-DEM still has an uncertainty of $100-200 \mathrm{~m}$ in some short sections due to artifacts derived from the data distribution, potential uncertainty of the geoid, and the column-averaged ice density. The error of ice velocity is about $5-10 \mathrm{~m} \mathrm{a}^{-1}$. Combining the errors of the velocity azimuth and the grounding line location, a $10 \%$ total error is assumed in calculated ice flux across the grounding line.

\subsection{Ice fluxes through the gates and basal fluxes beneath the flowbands}

Ice fluxes through the 18 gates over the flowbands are calculated using the InSAR velocity and ice thickness derived from the BEDMAP project and four DEMs. The 
mean velocity and ice thickness for the 18 gates over the flowbands are plotted in Figure 4. By combining the surface accumulation, basal fluxes between two gates can then be estimated. Values are quoted in Gt ice $\mathrm{a}^{-1}$ and $\mathrm{m}$ ice $\mathrm{a}^{-1}$ for ice flux and basal flux respectively using an ice density of $917 \mathrm{~kg} \mathrm{~m}^{-3}$.

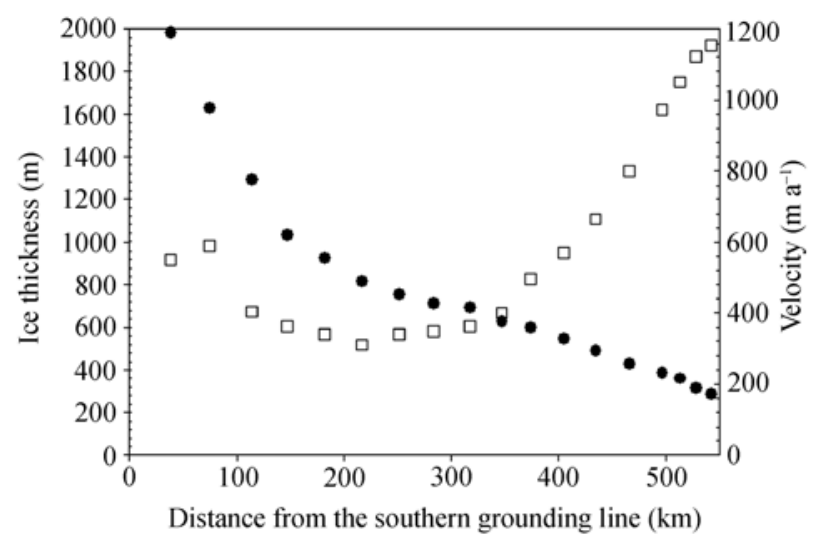

Figure 4 Mean thickness (dot) and ice velocity (square) for the 18 ice flux gates over the flowbands on the Amery Ice Shelf.

Ice velocity $\left(V_{i j}\right)$, thickness $\left(H_{i j}\right)$ and width $\left(\Delta X_{i j}\right)$ were derived from $400 \mathrm{~m}$ cell-size grids along the $i$ th gate, and ice flux $\left(F_{i}\right)$ across the $i$ th gate was calculated as

$$
F_{i}=\sum\left(\frac{V_{i j} H_{i j}+V_{i j+1} H_{i j+1}}{2}\right) \Delta X_{i j} \rho_{i},
$$

$j=1$ st $, \cdots,(n-1)$ th velocity, ice thickness and width

measurements

where $\rho_{i}$ is column-averaged ice density at the $i$ th gate.

Basal melting and freezing rate beneath an area defined by the adjacent two gates and the boundaries of the flowbands can be deduced from two gate fluxes $F_{i+1}$ downstream, $F_{i}$ upstream, and surface accumulation $\delta_{A}$, using conservation of mass as ${ }^{[11,15]}$

$$
\dot{B}=\frac{F_{i+1}-F_{i}-\delta_{A}}{\delta A},
$$

where $\delta A$ is the ice shelf area in between the two gates.

There are several sources of error in our estimate of ice fluxes through the gates and the basal melting and refreezing rates. InSAR velocity has an uncertainty of
$5-10 \mathrm{~m} \mathrm{a}^{-1}$, which is very small compared with the average velocities larger than $300 \mathrm{~m} \mathrm{a}^{-1}$ at any gate (Figure 4). The median absolute difference between observed and predicted ice thickness from BEDMAP is $23.95 \mathrm{~m}$, while the RMS of the kriging prediction error is $53.77 \mathrm{~m}$ over the Amery Ice Shelf. Fricker et al. ${ }^{[27,39]}$ estimated that the error in ice thicknesses interpolated across the southern portion has an upper limit of $\sim 200 \mathrm{~m}$ while the RMS of ice thickness differences at intersections of RES flight lines in the northwest part of the shelf is $26 \mathrm{~m}$. This implies the uncertainty of measured thickness is less than $8 \%$. The uncertainty of ice thickness originating from DEMs includes the errors from the DEM heights, column-averaged ice density and geoid model. Surface heights from three DEMs have an uncertainty of within $\pm 3 \mathrm{~m}$. The density model has an uncertainty of $5 \mathrm{~kg} \mathrm{~m}^{-3}$, which is consistent with the error analysis by Fricker et al. ${ }^{[27]}$. The geoid height fields may have errors of up to $3 \mathrm{~m}$ as evidenced by the differences taken between two geopotential models (OSU91A and EGM96) ${ }^{[27]}$. Combined, these errors may give an overall uncertainty of up to $40-50 \mathrm{~m}$ in ice thickness. Eqs. (1) and (2) then give maximum errors in $F_{i}$ and $\dot{B}$ of about $10 \%$ and $15 \%$ respectively, which are consistent with the swings of $F_{i}$ and $\dot{B}$ in Figures 5 and 6 .

\section{Results}

\subsection{Mass budgets of the Lambert, Mellor, and Fisher Glaciers}

The differences between the accumulation (input) and discharge (output) give the mass budgets for the Lambert, Mellor and Fisher Glaciers, upstream, downstream, and as a whole. The results with uncertainties are listed in Tables 1, 2 and 3 respectively.

From Tables 1 to 3 several features can be observed. First, Lambert and Mellor Glaciers upstream of the ANARE traverse line may have positive imbalances of $3.9 \pm 2.1 \mathrm{Gt} \mathrm{a}^{-1}$ and $2.1 \pm 2.4 \mathrm{Gt} \mathrm{a}^{-1}$ respectively while the Fisher Glacier is approximately in balance. The dif-

\begin{tabular}{|c|c|c|c|c|c|}
\hline Drainage & Area $\left(\mathrm{km}^{2}\right)$ & Average accumulation rate $\left(\mathrm{kg} \mathrm{m}^{-2} \mathrm{a}^{-1}\right)$ & Accumulation $\left(\mathrm{Gt} \mathrm{a}^{-1}\right)$ & Ice flux across traverse $\left(\mathrm{Gt} \mathrm{a}^{-1}\right)$ & Net budget $\left(\mathrm{Gt} \mathrm{a}^{-1}\right)$ \\
\hline Lambert & 373920 & 52.3 & $19.5 \pm 2.2$ & $17.4 \pm 0.9$ & $2.1 \pm 2.4$ \\
\hline Mellor & 373370 & 47.5 & $17.8 \pm 2.0$ & $13.9 \pm 0.7$ & $3.9 \pm 2.1$ \\
\hline Fisher & 53560 & 70.0 & $3.8 \pm 0.4$ & $3.9 \pm 0.2$ & $-0.1 \pm 0.5$ \\
\hline Total & 800850 & 51.2 & $41.0 \pm 4.6$ & $35.2 \pm 1.8$ & $5.9 \pm 4.9$ \\
\hline
\end{tabular}

Table 1 Accumulation, ice fluxes and mass budgets for the Lambert, Mellor and Fisher glaciers upstream the ANARE LGB traverse 
Table 2 Accumulation, ice fluxes and mass budgets for Lambert, Mellor and Fisher glaciers between the ANARE LGB traverse and the grounding line

\begin{tabular}{cccccccc}
\hline Drainage & Area $\left(\mathrm{km}^{2}\right)$ & $\begin{array}{c}\text { Average accumulation } \\
\text { rate }\left(\mathrm{kg} \mathrm{m}^{-2} \mathrm{a}^{-1}\right)\end{array}$ & $\begin{array}{c}\text { Accumulation } \\
\left(\mathrm{Gt} \mathrm{a}^{-1}\right)\end{array}$ & $\begin{array}{c}\text { Ice flux across } \\
\text { traverse }\left(\mathrm{Gt} \mathrm{a}^{-1}\right)\end{array}$ & $\begin{array}{c}\text { Total input }{ }^{\mathrm{a})} \\
\left(\mathrm{Gt} \mathrm{a}^{-1}\right)\end{array}$ & $\begin{array}{c}\text { Ice flux across grounding } \\
\left.\text { line }(\mathrm{Gt} \mathrm{a})^{-1}\right)\end{array}$ & $\begin{array}{c}\text { Net budget } \\
\left(\mathrm{Gt} \mathrm{a}^{-1}\right)\end{array}$ \\
\hline Lambert & 51000 & 59.8 & $3.1 \pm 0.3$ & $17.4 \pm 0.9$ & $20.5 \pm 0.9$ & $25.4 \pm 2.5$ & $-5.0 \pm 2.7$ \\
Mellor & 75220 & 63.0 & $4.7 \pm 0.5$ & $13.9 \pm 0.7$ & $18.6 \pm 0.9$ & $20.9 \pm 2.1$ & $-2.3+2.3$ \\
Fisher & 43530 & 59.5 & $2.6 \pm 0.3$ & $3.9 \pm 0.2$ & $6.5 \pm 0.4$ & $7.7 \pm 0.8$ & $-1.2+0.8$ \\
Total & 169750 & 61.1 & $10.4 \pm 1.2$ & $35.2 \pm 1.8$ & $45.5 \pm 2.1$ & $54.0 \pm 5.4$ & $-8.5 \pm 5.8$ \\
\hline
\end{tabular}

a) Equal to accumulation plus ice flux across the ANARE LGB traverse line.

Table 3 Accumulation, ice fluxes and mass budgets for the Lambert, Mellor and Fisher glaciers

\begin{tabular}{lccccc}
\hline Drainage & Area $\left(\mathrm{km}^{2}\right)$ & Average accumulation rate $\left(\mathrm{kg} \mathrm{m}^{-2} \mathrm{a}^{-1}\right)$ & Accumulation $\left(\mathrm{Gt} \mathrm{a}^{-1}\right)$ & Ice flux across grounding line $(\mathrm{Gt} \mathrm{a})$ & Net budget $(\mathrm{Gt} \mathrm{a})$ \\
\hline Lambert & 424930 & 53.2 & $22.6 \pm 2.3$ & $25.4 \pm 2.5$ & $-2.8 \pm 3.4$ \\
Mellor & 448590 & 50.1 & $22.5 \pm 2.3$ & $20.9 \pm 2.1$ & $1.6 \pm 3.0$ \\
Fisher & 97090 & 65.3 & $6.3 \pm 0.6$ & $7.7 \pm 0.8$ & $-1.3 \pm 1.0$ \\
Total & 970610 & 53.0 & $51.4 \pm 3.6^{\mathrm{a})}$ & $54.0 \pm 5.4$ & $-2.6 \pm 6.5$ \\
\hline
\end{tabular}

a) Error is determined assuming $5 \%$ for the average accumulation rate and $5 \%$ for the area.

ference between the total ice flux for the three glaciers across the traverse line and the total surface accumulation upstream is $5.9 \pm 4.9 \mathrm{Gt} \mathrm{a}^{-1}$, implying that the whole upstream region has a positive imbalance. Second, the three same glaciers downstream of the traverse line have a negative imbalance. The lower elevation region of the Lambert Glacier has a remarkable negative imbalance of $-5.0 \pm 2.7 \mathrm{Gt} \mathrm{a}^{-1}$. The difference between the total ice flux for the three glaciers across the southern grounding line and the total input (accumulation plus ice flux across the ANARE traverse line) is $-8.5 \pm 5.8 \mathrm{Gt} \mathrm{a}^{-1}$, suggesting that the downstream region as a whole has a negative imbalance. Third, overall the Lambert, Mellor, Fisher Glaciers are close to balance, with the entire drainage basin having a mass budget of $-2.6 \pm 6.5 \mathrm{Gt} \mathrm{a}^{-1}$. Fourth, the area of the Lambert and Mellor Glaciers upstream of the traverse line cover $77 \%$ of the drainage basin. This implies that most of the drainage basin is perhaps slightly thickening while the downstream portion is thinning.

\subsection{Basal melting and freezing beneath the flow- bands}

The fluxes through the southern grounding line and each gate are plotted in Figure 5. The ice flux across the grounding line is $58.9 \pm 5.9 \mathrm{Gt}_{\text {ice }} \mathrm{a}^{-1}$. At gate 8 , about $285 \mathrm{~km}$ from the southern extremity of the Amery Ice Shelf, the ice flux decreases to $9.7 \pm 1.0 \mathrm{Gt}$ ice $\mathrm{a}^{-1}$, then increases due to marine ice accreted to the bottom. Near the ice shelf front, it drops slightly due to a higher melting rate resulting from tidal pumping and the seasonally warmer waters of the coastal current ${ }^{[2]}$.
The basal melting and freezing rates beneath the three flowbands are plotted in Figure 6. The mean melting rate

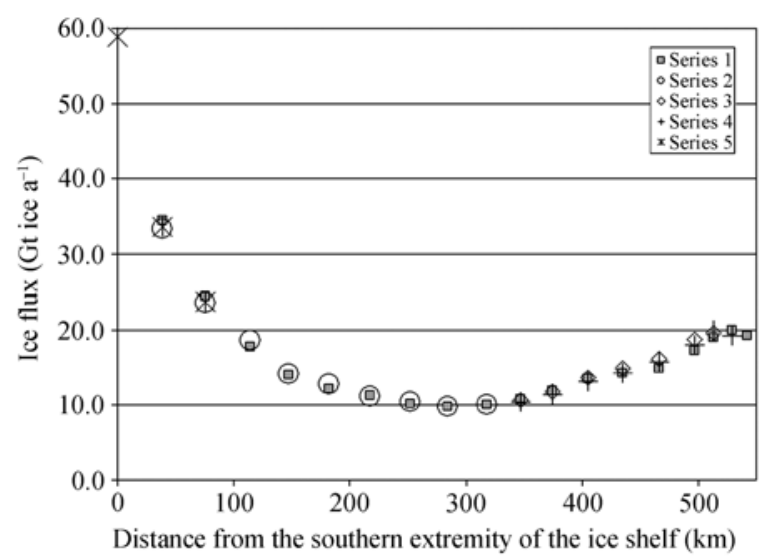

Figure 5 Ice fluxes across the gates over the flowbands on the Amery Ice Shelf. Series 1: Derived from AIS-DEM; 2: BEDMAP; 3: ANTARCTIC ALTAL-DEM; 4: OSU-DEM5; 5: GLAS-DEM.

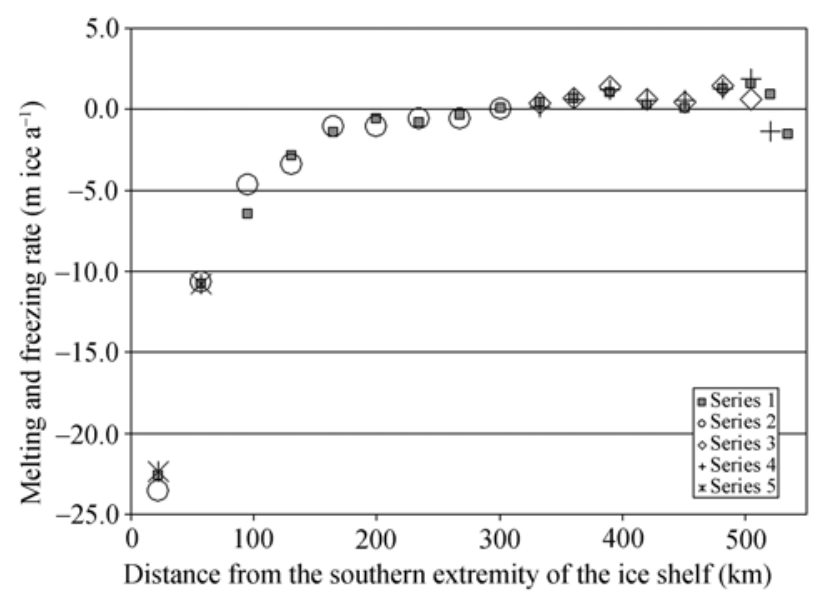

Figure 6 Basal melting and freezing rates beneath the flowbands on the Amery Ice Shelf. Series 1: Derived from AIS-DEM; 2: BEDMAP; 3: ANTARCTIC ALTAL-DEM; 4: OSU-DEM; 5: GLAS-DEM. 
is $-23.0 \pm 3.5 \mathrm{~m}$ ice $\mathrm{a}^{-1}$ near the southern grounding line, which decreases rapidly downstream, and transitions to refreezing at around $300 \mathrm{~km}$ north of the southern extremity of the ice shelf. Mean freezing rates of the flowbands are around $0.5 \pm 0.1$ to $1.5 \pm 0.2 \mathrm{~m}$ ice $\mathrm{a}^{-1}$. The total basal melting is $-50.3 \pm 7.5$ Gt ice $\mathrm{a}^{-1}$ (which includes part of the refrozen marine ice). The total marine ice accreted is $7.0 \pm 1.1 \mathrm{Gt}$ ice $\mathrm{a}^{-1}$.

\section{Discussion}

Besides the ANARE LGB traverse, in the early 1970s, eleven ice-movement stations were established further downstream of the LGB traverse ${ }^{[26]}$, which was referred to as GL line by Fricker et al. ${ }^{[24]}$. The stations at two ends of the GL line are beyond the margin of the Lambert and Fisher Glaciers (Figure 1). In situ measurements of ice velocity and thickness are available for use in mass-balance estimates. The normal velocity and the thickness distributions were integrated to derive a total mass flux of $29.7 \mathrm{Gt} \mathrm{a}^{-1}$ across the line $\mathrm{e}^{[26]}$, assuming a velocity ratio of 0.8 and a column-averaged ice density of $870 \mathrm{~kg} \mathrm{~m}^{-3}$. Using a velocity ratio of 0.87 and an ice density of $910 \mathrm{~kg} \mathrm{~m}^{-3}$, a total ice flux of $33.8 \mathrm{Gt} \mathrm{a}^{-1}$ was derived $^{[24]}$. In this study an ice flux of $36.9 \mathrm{Gt} \mathrm{a}^{-1}$ was derived using a velocity ratio of 0.95 that was inferred from a model simulation of the Antarctic ice sheet ${ }^{[41]}$. Allison ${ }^{[26]}$ obtained an overall positive imbalance for the interior upstream of the GL line of approximately $30 \mathrm{Gt}$ $\mathrm{a}^{-1}$ (50\% of total net accumulation) (Table 4$)$. Fricker et al. ${ }^{[24]}$ suggested that the mass balance of the region between the LGB and GL lines was significantly positive.

Here we define the interior basin upstream of the GL line by tracing the flowlines from the RADARSAT mosaic and the steepest path from the OSU-DEM. The area is $940820 \mathrm{~km}^{2}$, which is $13.7 \%$ less than the area given by Allison ${ }^{[26]}$, but larger than the area $\left(902000 \mathrm{~km}^{2}\right)$ reported by McIntyre ${ }^{[32]}$. We calculated a total net accumulation of $51.8 \mathrm{Gt} \mathrm{a}^{-1}$, which is about $8 \mathrm{Gt} \mathrm{a}^{-1}$ less than that reported by Allison ${ }^{[26]}$.

The region between the LGB and GL lines is delineated by tracing the steepest paths from the two GL line ends. The ice flux across the LGB traverse line into this region is $37.1 \mathrm{Gt} \mathrm{a}^{-1}$, and the total accumulation is 10.3 $\mathrm{Gt} \mathrm{a}^{-1}$, which yields a positive imbalance of $28.8 \%$ of the total input (ice flux through the LGB line plus the total accumulation in the region). The total accumulation of the region downstream of the GL line is $1.0 \mathrm{Gt} \mathrm{a}^{-1}$. Comparing the input (ice flux across the GL line plus the total accumulation downstream of the GL line) and output (the ice flux across the grounding line of the three glaciers), we calculate that the region downstream the GL line has a significant negative imbalance larger than $-16.1 \mathrm{Gt} \mathrm{a}^{-1}$, or $-42.5 \%$ of the total input (Table 4 ) because the GL line extends beyond the boundaries of Lambert and Fisher Glaciers.

The substantially larger positive imbalances for the interior basin upstream the GL line reported by Allison ${ }^{[26]}$ and Fricker et al. ${ }^{[24]}$ are possibly due to overestimating the total accumulation and/or underestimating of the ice flux through the GL line. The 11 ice-movement stations along the GL line are $50-100 \mathrm{~km}$ apart, which may result in a larger error for ice flux calculation, even though Allison ${ }^{[26]}$ interpolated surface velocities between the GL stations with reference to the ice thickness. It is more plausible that the ice flux was underestimated, which resulted in a large negative imbalance downstream of the GL line (compared with the ice flux across the grounding line in this study) and a large positive imbalance upstream of the line (Table 4, this study).

Our mass budget estimates show the Lambert, Mellor and Fisher Glaciers as a whole are close to a balance

Table 4 Mass budgets $\left(\mathrm{Gt} \mathrm{a}^{-1}\right)$ for the LGDB (as geographically defined by Allison ${ }^{[26]}$, Fricker et al. ${ }^{[24]}$ ) from different studies ${ }^{\text {a) }}$

\begin{tabular}{ccccc}
\hline Studies & Upsteam of GL line & Between LGB traverse and GL line & Between GL and grounding lines & Total drainage basin \\
\hline Allison (1979) & $+30(+50 \%)$ & - & $+12(+40 \%)$ & $+42(+70 \%)$ \\
McIntyre (1985) & $+2(+6 \%)$ & - & - & $+14(+44 \%)$ \\
Bentley \& Giovinetto (1991) & - & - & - & $+39(+78 \%)$ \\
Fricker et al. (2000b) & - & 4 of 6 budgets $>+30 \%$ & - & - \\
This study & $+14.9(+28.8 \%)$ & $+10.6(28.8 \%)$ & $-16.1(-42.5 \%)$ & $+9.1(+14.4 \%)$ \\
\hline
\end{tabular}

a) Bracketed values are ratios of mass budgets divided by total input; b) output value. We use the ice flux across the southern grounding line of the Lambert, Mellor and Fisher glaciers, is somewhat smaller than the actual ice flux through the grounding line of the LGDB. Therefore, mass imbalances for the region downstream of the GL line should be larger than $-16.1 \mathrm{Gt} \mathrm{a}^{-1}$, and for the whole basin should be smaller than $+9.1 \mathrm{Gt} \mathrm{a}^{-1}$. We use the new grounding line in our study (a detailed explanation for this table is in the accompanying text). 
state while the drainage region upstream of the LGB line (comparing $82.5 \%$ of the area of three glaciers) has a positive imbalance and downstream of the line has a negative imbalance, but the magnitudes are comparatively smaller than previously reported. Davis et al. ${ }^{[51]}$ estimated surface elevation change $(d H / d t)$ using Seasat and Geosat satellite radar altimeter measurements over the East Antarctic Ice Sheet for the period from 1978 to 1988. They obtained the $d H / d t$ estimate of $-2.3 \pm 2.2 \mathrm{~cm}$ $\mathrm{a}^{-1}$ north of $72.1^{\circ} \mathrm{S}$ (the southerly orbit limit of Seasat/ Geosat), and the ERS- $1 / 2 d H / d t$ estimate of $-1.8 \pm 1.7 \mathrm{~cm}$ $\mathrm{a}^{-1}$ north of $73.5^{\circ} \mathrm{S}$ for 1992 to 1996 computed using a subset of the published data from Wingham et al. ${ }^{[52]}$ in the LAS. These results show the lower portion of the three glaciers is probably thinning slightly, and are approximately consistent with our analysis indicating a negative mass budget downstream the LGB line. However, the most recent ERS radar altimetry assessment of elevation change from 1992-2003 indicates moderate thickening south and east of the Amery Ice Shelf in the $\mathrm{LAS}^{[4]}$. Possible explanations include: (1) Snow accumulation rates vary temporally. The altimetry results are more susceptible to the effects of temporal variability in snow accumulation and snow density ${ }^{[4,53,54]}$, while the mass budget estimate using the accumulation data spanning from the $1950 \mathrm{~s}$ to $1990 \mathrm{~s}^{[55]}$ gives a clearer indication of long-term ice sheet behavior ${ }^{[54]}$. (2) The discharge flux through the grounding line is not directly responding to the contemporary accumulation rate.

The boundaries of the three flowbands derived from velocity vector data are correlated with those derived from linear features, i.e., the dominant foliation trend and medial moraines ${ }^{[30]}$ in the second Antarctic Mapping Mission (MAMM) image mosaic ${ }^{[56]}$. For example, Fricker et al. ${ }^{[56]}$ suggested that Rift B was between the Fisher and Mellor flowbands, but the boundary between these two flowbands in this study is located mid-way between Rift B and Rift A at the calving front, which is about $15 \mathrm{~km}$ apart. Flow lines (the boundaries of the flowbands) inferred from velocity vectors indicate the present flow in the ice shelf while those drawn on the basis of the foliation trend and medial moraines have been incorporated into the ice over long periods of time. Variations between the positions of these two kinds of flow lines should show how ice flow has differed in the past 1000 years. Such differences are deduced from the distance and average velocity at the southern grounding line to the calving front, similar to the observations revealed by Jezek ${ }^{[57]}$ on the Ross Ice Shelf. The basal flux estimate in this study, however, is made by assuming that the ice shelf is in a steady state, an assumption supported by surface elevation and velocity data, which show little change between 1968 and the present ${ }^{[37,58]}$.

The total melting of ice discharge $\left(F_{M}\right)$ across the grounding line is estimated as

$$
F_{M}=F_{G L}-F_{I R}+\Phi A,
$$

where $F_{G L}$ is ice flux across the southern grounding line, $F_{I R}$ is the ice flux derived using Russian ice radar thickness at gate 18 , assuming that ice radar cannot penetrate the marine ice, and the signal is reflected at the meteoric-marine ice boundary; $\Phi A$ is the total accumulation over the three flowbands. $F_{M}$ of $43.3 \mathrm{Gt}$ ice $\mathrm{a}^{-1}$ is calculated by eq. (3), which is equal to $79.6 \%$ of the ice across the southern grounding line. If comparing the minimum ice flux of $9.7 \mathrm{Gt}_{\text {ice }} \mathrm{a}^{-1}$ at gate 8 with the ice flux through the grounding line, we calculate that the total basal melting of ice from the Lambert, Mellor and Fisher Glaciers is $49.2 \mathrm{Gt}$ ice $\mathrm{a}^{-1}$, or $83.6 \%$ of the ice from interior. From gate 8 the basal melting of the flowbands transits to freezing and the ice from interior loses little after that point. This implies that the percentage of ice lost from the interior by basal melting beneath the flowbands is about $80 \%$, with $5 \%$ uncertainty.

Our estimates of the total basal melting, refreezing and net basal mass loss beneath the three flowbands are $50.3 \pm 7.5$ Gt ice $\mathrm{a}^{-1}, 7.0 \pm 1.1 \mathrm{Gt}$ ice $\mathrm{a}^{-1}$ and $43.3 \pm 6.5 \mathrm{Gt}$ ice $\mathrm{a}^{-1}$ for the Lambert, Mellor and Fisher Glaciers, respectively. The total basal melting and net melting are much larger than the results inferred from modeling ${ }^{[35-37]}$ and oceanographic data from Prydz Bay ${ }^{[33]}$ for the entire Amery Ice Shelf. The marine ice beneath the three flowbands only covers about one third of the total area which is concentrated in the northwest of the shelf ${ }^{[38]}$. The total basal refreezing beneath the Amery Ice Shelf is, therefore, much larger than $7.0 \mathrm{Gt}$ ice $\mathrm{a}^{-1}$ (the total refreezing beneath the three flowbands), and also much larger than the basal freezing of several $\mathrm{Gt}^{-1}$ from modeling ${ }^{[37]}$, which forms an accreted ice layer up to $190 \mathrm{~m}$ thick and accounts for about $9 \%$ of the shelf volume ${ }^{[38]}$. The possible reason for the smaller values derived from oceanography is the small number of 1992 CTD casts across the ice shelf front ${ }^{[59]}$; a much more thorough hydrographic survey was undertaken by ANARE and CHINARE in 2001, 2002 and 2003, so 
future studies may resolve the interaction at the base of the shelf in more detail, combined with the data recovered from the access holes through the shelf. The geometry of the ice shelf and the dimensions of the sub-ice cavity play an important role in the modeling of processes that occur beneath the ice shelf, such as basal melting, refreezing, and sub-shelf ocean circulation and tides. Only recently was the grounding line of the shelf defined by hydrostatic equilibrium and $\operatorname{InSAR}{ }^{[15,27]}$, which resulted in the Amery Ice Shelf extending an additional $\sim 240 \mathrm{~km}$ upstream of the previously reported position. For example, Hellmer and Jacobs ${ }^{[35]}$ were not able to simulate the amount of marine ice observed at the 1968 borehole site near G1. With the substantial southward extension of the shelf boundary and the subice cavity, the modeling may now be able to match the results from this study. Our results indicate that the basal melting, freezing and net melting are much larger than previously reported, and that the net basal melting accounts for most of the ice loss from the three glaciers.

Gate 1 is located at approximately the same position as the flux gate located about one glacier-width downstream of the grounding line reported by Rignot ${ }^{[15]}$ and Rignot and Jacobs ${ }^{[11]}$. The melting rate between the grounding line and gate 1 is $23.0 \pm 3.5 \mathrm{~m}^{\text {ice }} \mathrm{a}^{-1}$ in this study, which is only about three fourth of the $31 \pm 5 \mathrm{~m}$ ice $\mathrm{a}^{-1}$ reported by Rignot and Jacobs ${ }^{[11]}$, though still within the uncertainty limits. This is possibly due to different DEMs used to estimate the ice fluxes across the southern grounding line and gate 1 in the two studies. Our estimates of the ice fluxes across the grounding line and gate 1 are $58.9 \pm 5.9$ Gt ice $\mathrm{a}^{-1}$ and $33.7 \pm 3.4$ Gt ice $\mathrm{a}^{-1}$ respectively over an area of $1083 \mathrm{~km}^{2}$, corresponding to $57.5 \pm 5 \mathrm{Gt}$ ice $\mathrm{a}^{-1}$ and $28.4 \pm 2 \mathrm{Gt}$ ice $\mathrm{a}^{-1}$ reported by Rignot $^{[15]}$ over an area of $913 \mathrm{~km}^{2}$. The ice flux across gate 1 is larger than that estimated by Rignot ${ }^{[15]}$.

The spatial distribution of melting and refreezing beneath the three flowbands is similar to the standard conceptual and numerical models in which most melt occurs near the grounding lines ${ }^{[11]}$, but differs significantly from the results reported by Joughin and Padman ${ }^{[19]}$. They found that roughly two thirds $\left(54 \mathrm{Gt} \mathrm{a}^{-1}\right)$ of the net melt beneath the Filchner-Ronne Ice Shelf is generated at shallow depths (mean $375 \mathrm{~m}$ ) near the Ronne Ice Shelf front. Relatively fresh, supercooled water plumes containing platelet crystals have been observed north of the ice front in western Prydz Bay ${ }^{[60]}$. The temperature values immediately below the Amery Ice Shelf measured by $\mathrm{CTD}$ are $-2.25^{\circ} \mathrm{C}$ at $\mathrm{AM} 01$ and $-2.14^{\circ} \mathrm{C}$ at $\mathrm{AM} 02^{[61]}$. This subfreezing ice shelf water may still be a main control of the melting and freezing processes at the base near the ice shelf front, and may mitigate the melting associated with tidal pumping.

\section{Conclusions}

We have assessed the mass budgets of three major glaciers, the Lambert, Mellor and Fisher, that feed the Amery Ice Shelf, and the basal melting and freezing beneath their flowbands on the Amery Ice Shelf using a variety of data sets.

The mass budgets of the Lambert, Mellor, Fisher Glaciers are $-2.8 \pm 3.4 \mathrm{Gt} \mathrm{a}^{-1}, 1.6 \pm 3.0 \mathrm{Gt} \mathrm{a}^{-1}$ and $-1.3 \pm 1.0$ $\mathrm{Gt}^{-1}$, suggesting that the three glaciers are close to balance. The whole drainage basin of the three glaciers is nearly in balance with a mass budget of $-2.6 \pm 6.5 \mathrm{Gt}$ $\mathrm{a}^{-1}$. However, upstream of the ANARE LGB traverse line, the three glaciers collectively have a positive imbalance of $5.9 \pm 4.9 \mathrm{Gt} \mathrm{a}^{-1}$ while downstream they have a negative imbalance of $-8.5 \pm 5.8 \mathrm{Gt} \mathrm{a}^{-1}$.

The larger positive mass imbalance reported by Allison $^{[26]}$, Bentley and Giovinetto ${ }^{[1]}$ for the entire LGDB (Table 4) is due mainly to the incorrect positioning of the grounding line, while the comparatively lower positive imbalance presented by McIntyre ${ }^{[32]}$ is due mainly to a considerable underestimate of the total net accumulation for this region. The larger positive mass imbalances for the interior basin upstream of the GL line presented by Allison ${ }^{[26]}$ and Fricker et al. ${ }^{[24]}$ are possibly due to overestimates of the total accumulation and underestimates of the ice flux through the GL line. Our analysis of mass budgets for the Lambert, Mellor and Fisher Glaciers in this study and the $d H / d t$ estimates derived from satellite radar altimeters ${ }^{[4,52]}$ suggest that the interior basin upstream of the GL line is likely to be close to balance or to have a positive imbalance.

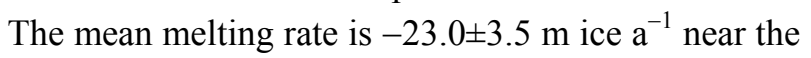
southern grounding line, which decreases rapidly downstream, transitions to refreezing at around $300 \mathrm{~km}$ northward of the southern extremity of the Amery Ice Shelf. Mean freezing rates of the flowbands are around

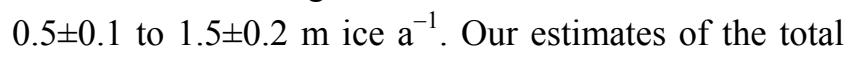
basal melting, refreezing and total basal mass loss beneath the Lambert, Mellor and Fisher flowbands are 
50.3 \pm 7.5 Gt ice $\mathrm{a}^{-1}, 7.0 \pm 1.1 \mathrm{Gt}$ ice $\mathrm{a}^{-1}$ and $43.3 \pm 6.5 \mathrm{Gt}$ ice $\mathrm{a}^{-1}$ respectively. The total basal melting and net melting are much larger than the results inferred from modeling $[35-37]$ and oceanographic data from Prydz Bay ${ }^{[33]}$ for the entire Amery Ice Shelf. The percentage of ice lost from the interior by basal melting beneath the flowbands is about $80 \% \pm 5 \%$. This result indicates that basal melting and freezing are significant components of the mass budget of the Amery Ice Shelf, and vigorous interaction occurs at the ice-ocean interface.

The spatial distribution of melting and refreezing beneath the three flowbands is similar to the standard conceptual and numerical models in which most melt occurs

1 Bentley C R, Giovinetto M R. Mass balance of Antarctica and sea level change. In: Weller G, Wilson C L, Severin B AB, eds. Collection in International Conference on the Role of the Polar Regions in Global Change: Proceedings of a Conference Held June 11-15, 1990 at the University of Alaska Fairbanks. Vol II. Fairbanks: Geophysical Institute/Center for Global Change and Arctic System Research, University of Alaska, 1991. 481-488

2 Jacobs S S, Helmer H H, Doake C S M, et al. Melting of ice shelves and the mass balance of Antarctica. J Glaciol, 1992, 38(130): $375-387$

3 Rignot E, Thomas R H. Mass balance of polar ice sheets. Science, 2002, 297: 1502-1506[DOI]

4 Davis C H, Li Y, McConnell J R et al. Snowfall-driven growth in East Antarctic Ice Sheet mitigates recent sea-level rise. Science, 2005, 308: 1898-1901[DOI]

5 Zwally H J, Giovinetto M B, Li J, et al. Mass changes of the Greenland and Antarctic ice sheets and shelves and contributions to sea-level rise: 1992-2002. J Glaciol, 2005, 51(175): 509-527

6 Velicogna I, Wahr J. Measurements of time-variable gravity show mass loss in Antarctica. Science, 2006, 311: 1754-1756[DOI]

7 Whillans I M, Bindschadler R A. Mass balance of Ice Stream B, West Antarctica. Ann Glaciol, 1998, 11: 187-193.

8 Berthier E, Raup B, Scambos E. New velocity map and mass- balance estimate of Mertz Glacier, East Antarctica, derived from Landsat sequential imagery. J Glaciol, 2003, 49(167): 503-511

9 The ISMASS Committee. Recommendations for the collection and synthesis of Antarctic Ice Sheet mass balance data. Glob Planet Change, 2004, 42: 1-15[DOI]

10 Jacobs S S, Hellmer H H, Jenkins A. Antarctic ice sheet melting in the Southeast Pacific. Geophys Res Lett, 1996, 23(9): 957-960[DOI]

11 Rignot E, Jacobs S S. Rapid bottom melting widespread near Antarctic Ice Sheet grounding lines. Science, 2002, 296: 2020-2023[DOI]

12 Jenkins A and Doake C S M. Ice-ocean interaction on Ronne Ice Shelf, Antarctica. J Geophys Res, 1991, 96(C1): 791-813

13 Gray L, Short N, Bindschadler R, et al. RADARSAT interferometry for Antarctic grounding-zone mapping. Ann Glaciol, 2002, 34: $269-276$

14 Joughin I, Tulaczyk S. Positive mass balance of the Ross ice streams, along the grounding lines $\frac{[11]}{}$, but differs significantly from the results reported by Joughin and Padman $\frac{[19]}{\text { for }}$ the Filchner-Ronne Ice Shelf.

The authors would like to thank M. B. Giovinetto and D. G. Vaughan for providing us with the accumulation compilations, Tan Dejun for providing the ice core density data (especially, M. B. Giovinetto who provided us a newly modified accumulation compilation used in this study). The ICESat GLAS data were provided by the OSU Science Computing Facility. Some of the data used within this paper were obtained from the Australian Antarctic Data Centre (IDN Node AMD/AU), a part of the Australian Antarctic Division (Commonwealth of Australia). The data are described in the metadata records "Radio-echo sounding (RES) ice thickness data: LGB traverses 1990-95" Allison, I. (1999) and "Ice sheet surface velocity data: LGB traverses 1989-95" Allison, I. (1999).

West Antarctica, Science, 2002, 295: 476-480[DOI]

15 Rignot E. East Antarctic glaciers and ice shelves mass balance from satellite data. Ann Glaciol, 2002, 34: 228-234

16 Liu H, Jezek K C, Li B. Development of an Antarctic digital elevation model by integrating cartographic and remotely sensed data: A geographic information system based approach, J Geophys Res, 1999, 104(B10): 23199-23214[DOI]

17 Zwally H J, Schutz B, Abdalati W, et al. ICESat's laser measurements of polar ice, atmosphere, ocean, and land. J Geodyn, 2002, 34 (3-4): $405-445$ [DOI]

18 Herzfeld U C, ed. Atlas of Antarctica: Topographic Maps From Geostatistical Analysis of Satellite Radar Altimeter Data. New York . Tokyo: Springer Verlag Heidelberg, 2004. 1-65

19 Joughin I, Padman L. Melting and freezing beneath Filchner- Ronne Ice Shelf, Antarctica. Geophys Res Lett, 2003, 30(9): 1477[DOI]

20 Vaughan D G, Bamber J L, Giovinetto M B, et al. Cooper reassessment of net surface mass balance in Antarctica. J Climate, 1999, 12(4): 933-946[DOI]

21 Giovinetto M B, Zwally H J. Spatial distribution of net surface accumulation on the Antarctic ice sheet. Ann Glaciol, 2000, 31: 171178

22 Lythe M B, Vaughan D G. The BEDMAP Consortium. BEDMAP: A new ice thickness and subglacial topographic model of Antarctica. J Geophys Res, 2001, 106(B6): 11335-11351[DOI]

23 Fricker H A, Hyland G, Coleman R, et al. Digital elevation models for the Lambert Glacier-Amery Ice Shelf system, East Antarctica, from ERS-1 satellite radar altimetry. J Glaciol, 2000, 46(155): 553-560

24 Fricker H A, Warner R C, Allison I. Mass balance of the Lambert Glacier-Amery Ice Shelf system, East Antarctica: a comparison of computed balance fluxes and measured fluxes. J Glaciol, 2000, 46(155): $561-570$

25 Jezek K C. Glaciological properties of the Antarctic ice sheet from RADARSAT-1 synthetic aperture radar imagery. Ann Glaciol, 1999, 29: $286-290$

26 Allison I. The mass budget of the Lambert Glacier drainage basin, Antarctica. J Glaciol, 1979, 22(87): 223-235

27 Fricker H A, Allison I, Craven M et al. Redefinition of the Amery Ice Shelf, East Antarctica, grounding zone. J Geophys Res, 2002, 
107(B5): 2092[DOI]

28 Budd W F, Corry M J, Jacka T H. Results from the Amery Ice Shelf project. Ann Glaciol, 1982, 3: 36-41

29 Wu X, Jezek K C. Antarctic ice-sheet balance velocities from merged point and vector data, J Glaciol, 2004, 50(169): 219-230

30 Hambrey M J, Dowdeswell J A. Flow regime of the Lambert GlacierAmery Ice Shelf system, Antarctica: structural evidence from Landsat imagery. Ann Glaciol, 1994, 20: 401-406

31 Jezek K C. Observing the Antarctic Ice Sheet using the RADARSAT-1 synthetic aperture radar. Polar Geography, 2003, 27(3): 197-209

32 McIntyre N F. A re-assessment of the mass balance of the Lambert Glacier drainage basin, Antarctica. J Glaciol, 1985, 31(107): 34-38

33 Wong A P S, Bindoff N L, Forbes A. Ocean-ice shelf interaction and possible bottom water formation in Prydz Bay, Antarctica. In: Jacobs S S, Weiss R F, eds. Collection in Ocean, Ice, and Atmosphere: Interactions at the Antarctic Continental Margin, Antarct Res Ser, Vol. 75. Washington, D. C.: AGU, 1998. 173-187

34 Morgan V I. Oxygen isotope evidence for bottom freezing on the Amery Ice Shelf. Nature, 1972, 238: 393-394

35 Hellmer H H, Jacobs S S. Ocean interactions with the base of Amery Ice Shelf, Antarctica. J Geophys Res, 1992, 97, 20: 305-20, 317

36 Hellmer H H. Impact of Antarctic ice shelf basal melting on sea ice and deep ocean properties. Geophys Res Lett, 2004, 31: L10307[DOI]

37 Williams M J M, Grosfeld K, Warner R C, et al. Ocean circulation and ice-ocean interaction beneath the Amery Ice Shelf, Antarctica. J Geophys Res, 2001, 106(C10), 22: 383-22400

38 Fricker H A, Popov S, Allison I, et al. Distribution of marine ice beneath the Amery Ice Shelf. Geophys Res Lett, 2001, 28(11): $2241-2244$ [DOI]

39 Jezek K C. RADARSAT-1 Antarctic mapping project: change-detection and surface velocity campaign. Ann Glaciol, 2002, 34: 263-268

40 Zwally H J, Schutz R, Bentley C, et al. Updated current year. GLAS/ ICESat L2 Antarctic and Greenland Ice sheet altimetry data V018, 15 October to 18 November 2003. Boulder, CO, National Snow and Ice Data Center. Digital media. 2003

41 Huybrechts P. Sea-level changes at the LGM from ice-dynamic reconstructions of the Greenland and Antarctic ice sheets during the glacial cycles. Quat Sci Rev, 2002, 21(1-3): 203-231[DOI]

42 Joughin I R, Kwok R, Fahnestock M A. Interferometric estimation of three-dimensional ice-flow using ascending and descending passes. IEEE Trans Geosci Remote Sensing, 1998, GE-36(1): 25-37[DOI]

43 Rapp R H, Wang Y M, Pavlis N K. The Ohio State 1991 geopotential and sea surface topography harmonic coefficient models, Rep. 410, Dept. of Geodet. Sci. and Surv., Ohio State Univ., Columbus, 1991

44 Hemer M, Harris P. Sediments collected from beneath the Amery Ice Shelf, East Antarctica, document sub-ice-shelf circulation of water and sediments throughout the Holocene. FRISP Report No. 15, 2004

45 Kiernan R. Ice sheet surface velocities along the Lambert Glacier Basin traverse route. Antarctic CRC Research Report No.23, 1-76.
Cooperative Research Centre for Antarctica and the Southern Ocean, University of Tasmania. Hobart. 2001

46 Manson R, Coleman R, Morgan P, et al. Ice velocities of the Lambert Glacier from static GPS observations, Earth Planets Space, 2000, 52: 1031- 1036

47 Craven M, Higham M, Brocklesby A. Ice thickness and surface \& bedrock elevations from the Lambert Glacier Basin traverses 1990-1995. Antarctic CRC Research Report No.23, 1-76. Cooperative Research Centre for Antarctica and the Southern Ocean, University of Tasmania. Hobart. 2001

48 Thomas R H, Csathó B M, Gogineni S, et al. Thickening of the western part of the Greenland ice sheet. J Glaciol, 1998, 46(155): $653-658$

49 Thomas R, Akins T, Csathó B M, et al. Mass balance of the Greenland ice sheet at high elevations. Science, 2000, 289(5478): 426-428[DOI]

50 Wen J, Jezek K C, Monaghan A J, et al. Accumulation variability and mass budgets of the Lambert Glacier-Amery Ice Shelf system at high elevations, Ann Glaciol, 2006, 43: 351-360

51 Davis C H, Belu R G, Feng G. Elevation change measurement of the East Antarctic Ice Sheet, 1978-1988, from satellite radar altimetry. IEEE Trans Geosci Remote Sensing, 2001, 39(3): 635-644[DOI]

52 Wingham D J, Ridout A J, Scharroo R, et al. Antarctic elevation change from 1992-1996. Science, 1998, 282: 456-458 [DOI]

53 McConnell J R, Arthern R J, Mosley-Thompson E, et al. Changes in Greenland ice sheet elevation attributed primarily to snow accumulation variability. Nature, 2000, 406: 877-879 [DOI]

54 Thomas R, Csathó B M, Davis C, et al. Mass balance of higher-elevation parts of the Greenland ice sheet. J Geophys Res, 2001, 106(D24): 33707-33716[DOI]

55 Higham M, Craven M, Ruddell A, et al. Snow-accumulation distribution in the interior of the Lambert Glacier basin, Antarctica. Ann Glaciol, 1997, 25: 412-417

56 Fricker H A, Young N W, Allison I, et al. Iceberg calving from the Amery Ice Shelf, East Antarctica. Ann Glaciol, 2002, 34: 241-246

57 Jezek K C. Recent changes in the dynamic condition of the Ross Ice Shelf, Antarctica. J Geophys Res, 1984, 89 (B1): 409-416

58 Phillips H A. Applications of ERS satellite radar altimetry in the Lambert Glacier-Amery Ice Shelf system, East Antarctica. Dissertation for the Doctoral Degree, Hobart, Univ. of Tasmania, Australia. 1999, 1-308

59 Allison I. The AMISOR project: ice shelf dynamics and ice-ocean interaction of the Amery Ice Shelf, FRISP Report No. 14, 2003

60 Penrose J, Conde M, Pauly T. Acoustic detection of ice crystals in Antarctic waters. J Geophys Res, 1994, 99(C6): 12573-12580[DOI]

61 Leffanue H, Craven M. Circulaition and water masses from current meter and T/S measurements at the Amery Ice Shelf. FRISP Report No. 15,2004 